\title{
Molecular Docking of Active Compounds Piper crocatum on The Alpha- Glucosidase Enzyme as Antidiabetic
}

\author{
Mustika Weni*, Mega Safithri, Djarot S.H. Seno \\ Department of Biochemistry, Faculty of Mathematics and Natural Sciences, Bogor Agricultural University, Bogor \\ 16680,West Java Indonesia
}

Submitted 16 March 2019; Revised 27 March 2020; Accepted 30 March 2020; Published 10 June 2020

*Corresponding author:mustikaweni261192@gmail.com

\begin{abstract}
Ethanol extract of Piper crocatum leaves has inhibitory activity of $\alpha$-glucosidase enzyme. Ethyl acetate fraction from Piper crocatum leaves has the highest antioxidant activity and has an inhibition of $\alpha$-glucosidase containing 6XO32ZSP1D, Ethyl L-serinate hydrochloride compound, Schisandrin B compound, Columbin compound, 4-(4-methoxy-phenylamino)-2 compound, 3-dihydro-1H-4a, 9-diazacyclopenta (b) fluorine-10-carbonitrile, compound 6-Amino-4-[3-(benzyloxy)phenyl] -3-tertbutyl-2,4-dihydropyrano [2,3-c] pyrazole-5-carbonitrile, compound 4- $\{\{4$-6-Bis [(3R,5S)-3,5-diamino1-piperydinyl] -1,3,5-triazine-2-yl \}amino) benzenesulfonamide and compound 1.1'-(1,4-butanediyl) bis $\{2,6$-dimethyl-4-[(3-methyl-1,3-benzothiazol-2(3H) ylidene) methyl]pyridinium. This study aims to obtain the interaction between bioactive compounds contained in ethyl acetate fraction of Piper crocatum leaves with $\alpha$-glucosidase enzyme in In Silico using AutoDock Vina, Columbin shows the lowest binding energy with binding sites with amino acids Ser240, Asp242, His280, Arg315, Glu411, Phe159, Arg442, Tyr 158 and Phe303. Columbin has the stability and inhibits the $\alpha$-glucosidase enzyme from $S$. cerevisiae better than the seven other compounds, because it has $\mathrm{OH}$ and $\mathrm{CH}_{3}$ groups which play a role in the interaction with around the active side of the $\alpha$-glucosidase enzyme.
\end{abstract}

Keywords: Columbin, in Silico, $\alpha$-Glucosidase

\section{Penambatan Molekuler Senyawa Aktif Daun Sirih Merah (Piper Crocatum) terhadap Enzim Alfa-Glukosidase sebagai Antidiabetes}

\begin{abstract}
Abstrak
Ekstrak etanol daun sirih merah memiliki aktivitas penghambatan enzim $\alpha$-glukosidase. Fraksi etil asetat daun sirih merah memiliki aktivitas antioksidan tertinggi dan memiliki penghambatan terhadap $\alpha$-glukosidase dengan kandungan 6XO32ZSP1D, Ethyl L-serinate hydrochloride, Schisandrin B, Columbin, 4-(4-methoxy-phenylamino)-2,3-dihydro-1H-4a,9-diazacyclopenta(b) fluorine-10-carbonitrile, 6-Amino-4-[3-(benzyloxy)phenyl]-3-tert-butyl-2,4-dihydropyrano[2,3-c] pyrazole-5-carbonitrile, 4-(\{4,6-Bis[(3R,5S)-3,5-diamino-1-piperydinyl]-1,3,5-triazin-2-yl $\}$ amino $)$ benzenesulfonamide dan 1,1'-(1,4-butanediyl)bis \{2,6-dimethyl-4-[(3-methyl-1,3-benzothiazol-2(3H) ylidene)methyl]pyridinium. Penelitian bertujuan untuk mempelajari interaksi antara senyawa bioaktif yang terkandung dalam fraksi etil asetat daun sirih merah dengan enzim $\alpha$-glukosidase secara In Silico dengan menggunakan AutoDock Vina, Columbin menunjukkan energi pengikatan terendah dengan situs pengikatan dengan asam amino Ser240, Asp242, His280, Arg315, Glu411, Phe159, Arg442, Tyr158 dan Phe303. Columbin mempunyai stabilitas dan menginhibisi enzim $\alpha$-glukosidase dari $S$. cerevisiae lebih baik daripada ketujuh senyawa lain, karena memiliki gugus $\mathrm{OH}$ dan $\mathrm{CH}_{3}$ yang berperan dalam interaksi dengan sekitar sisi aktif dari enzim $\alpha$ - glukosidase.
\end{abstract}

Kata Kunci: Columbin, in Silico, $\alpha$-Glukosidase 


\section{Pendahuluan}

Diabetes melitus adalah suatu penyakit yang ditandai dengan penurunan sekresi dan resistensi insulin atau keduanya karena kelainan metabolik yang menyebabkan naiknya kadar glukosa darah (hiperglikemia) pada kondisi normal. ${ }^{1}$ Terdapat dua jenis prevalen dari penyakit ini, yang biasa dikenal dengan diabetes melitus tipe 1 dan tipe 2. DM tipe 2 ini lebih umum, mencapai 90-95\% dari populasi DM. ${ }^{2}$ Pengobatan yang paling umum untuk DM 2 adalah dengan menghambat Enzim $\alpha$-glukosidase. Enzim $\alpha$-glukosidase adalah enzim yang berperan dalam pemecahan karbohidrat menjadi glukosa dan dapat meningkatkan kadar glukosa darah, sehingga untuk mencegah naiknya gula darah maka dibutuhkan suatu inhibitor enzim $\alpha$-glukosidase. Inhibitor $\alpha$-glukosidase menghambat enzim $\alpha$-glukosidase yang menguraikan pati dalam usus halus sehingga menunda penyerapan glukosa hasil pemecahan karbohidrat di dalam usus halus sehingga dapat menurunkan kadar gula darah postprandial. ${ }^{3}$ Inhibitor enzim $\alpha$-glukosidase standar yang telah diakui oleh WHO dan IDF adalah akarbose dan miglitol, ${ }^{4}$ namun obat ini juga dilaporkan menyebabkan berbagai efek samping seperti kembung, mual, diare dan flatulensi. Hal ini menyebabkan penelitian tentang senyawa inhibitor $\alpha$-glukosidase dari bahan alam yang minim efek samping menjadi penting.

Indonesia merupakan negara tropis yang kaya dengan berbagai jenis tanaman. Terdapat banyak tumbuhan obat yang dilaporkan bermanfaat dan digunakan sebagai agen antidiabetes secara empiris. Kandungan senyawa kimia dalam tumbuhan dilaporkan aman untuk penderita DM. ${ }^{5}$ Rebusan daun sirih merah secara turun temurun dipercaya dapat menurunkan kadar glukosa darah. Daun sirih merah (Piper crocatum) mengandung senyawa aktif seperti flavonoid, alkaloid, tanin, minyak atsiri, ${ }^{6}$ fenol dan saponin. ${ }^{7}$ Berdasarkan penelitian yang dilakukan secara in vitro dan in vivo, daun sirih merah dapat memberikan efek hipoglikemik sebagai inhibitor $\alpha$-glukosidase. Kandungan senyawa senyawa kimia yang terdapat didalam daun sirih merah tersebut memiliki aktivitas antidiabetes ditunjukkan dengan pemberian dosis $1350 \mathrm{mg} / \mathrm{kg}$ BB menurunkan kadar glukosa darah tikus yg diinduksi streptozotocin sebesar $38.95 \%,{ }^{8}$ Pemberian ekstrak etanol sirih merah dosis $200 \mathrm{mg} / \mathrm{kg}$ bb dapat menurunkan kadar glukosa darah pada tikus Wistar jantan model hiperkolesterolemia. ${ }^{9}$ Alfarabi et al. menyatakan bahwa daun sirih merah (Piper crocatum) dengan kandungan bioaktif fenol, flavonoid, alkaloid, dan triterpenoid mampu menghambat aktivitas $\alpha$-glukosidase sebesar $39.62 \%{ }^{10}$ Sebagai awal dari pencarian obat antidiabetes baru, dilakukan penelitian dengan pendekatan in silico (molecular docking) untuk mengetahui interaksi penambatan molekuler senyawa aktif fraksi etil asetat daun sirih merah dengan enzim $\alpha$-glukosidase, dimana interaksi penghambatan enzim berkerja pada sisi aktif enzim $\alpha$-glukosidase yaitu Asp69, His112, Arg213, Asp215, Glu277, His351, Arg442 dan Asp352. ${ }^{11}$

Berdasarkan penelitian sebelumnya yang dilakukan oleh Weni et al. menyatakan bahwa fraksi etil asetat daun sirih merah memiliki aktivitas terhadap enzim $\alpha$-glukosidase yang lebih tinggi dibandingkan dengan ekstrak etanol $70 \%,{ }^{12}$ Fraksi air dan Fraksi n-heksan daun sirih merah dengan nilai $\mathrm{IC}_{50}$ sebesar $743.80 \mu \mathrm{g} / \mathrm{ml}$. Senyawa aktif yang terkandung didalam daun sirih merah telah dianalisis dengan LCMS, diperoleh 8 senyawa : 6XO32ZSP1D, Ethyl L-serinate hydrochloride, senyawa Schisandrin B, senyawa Columbin, senyawa 4-(4-methoxy-phenylamino)2,3-dihydro-1H-4a,9-diazacyclopenta(b) fluorine-10-carbonitrile, senyawa 6-Amino4-[3-(benzyloxy)phenyl]-3-tert-butyl-2,4dihydropyrano[2,3-c]pyrazole-5carbonitrile, senyawa 4-(\{4,6-Bis[(3R,5S)-3,5-diamino1 -piperydiny 1$]-1,3,5$ triazin $2 y 1\}$ amino) benzensulfonamide dan 1,1'-(1,4-butanediyl) bis $\{2,6$-dimethy $1-4-[(3-$ methy $1-1,3-$ benzothiazol-2(3H)ylidene)methyl] pyridinium. ${ }^{13}$ Namun demikian penelitian secara komputasi terhadap kedelapan senyawa untuk melihat interaksi antara ligan dengan residu katalitik $\alpha$-glukosidase belum 
pernah dilakukan. Penelitian ini bertujuan untuk mengetahui afinitas ligan terhadap enzim glukosidase dan mempelajari interaksi antara senyawa bioaktif yang terkandung dalam fraksi etil asetat daun sirih merah dengan enzim $\alpha$-glukosidase secara In Silico dengan menggunakan AutoDock Vina. Adapun manfaat dari penelitian ini diharapkan memperoleh informasi tambahan mengenai senyawa yang berpotensi sebagai inhibitor enzim glukosidase.

\section{Metode}

2.1. Alat

Peralatan yang digunakan yaitu seperangkat laptop dengan menggunakan Software yang terdiri dari Autodock Tools, Autodock Vina, Discovery Studio dan Ligplot. Protein Data Bank (http://www.rcsb. org/pdb), PubChem (http://PubChem.ncbi. nlm.nih.gov).

\subsection{Bahan}

Struktur3D $\alpha$-glukosidaseyang diunduh dari Protein Data Bank dengan format .pdb dengan kode PDB (PDB ID : 3a4a). Struktur 3D ligan yang dipakai adalah 6XO32ZSP1D, Ethyl L-serinate hydrochloride, Schisandrin B, Columbin, 4-(4-methoxyphenylamino)-2,3-dihydro-1 H-4a,9diazacyclopenta(b)fluorine-10-carbonitrile, 6-Amino-4-[3-(benzyloxy)phenyl]-3 tert-butyl-2,4-dihydropyrano[2,3-c] pyrazole-5-carbonitrile, $4-(\{4,6-\mathrm{Bis}[(3 \mathrm{R}, 5 \mathrm{~S})-$ 3,5-diamino-1-piperydinyl]-1,3,5-triazin2-yl \}amino)benzenesulfonamide dan 1,1 '-(1,4-butanediyl)bis $\{2,6$-dimethyl-4[(3-methyl-1,3-benzothiazol-2(3H)ylidene) methyl]pyridinium yang diunduh dari PubChem dengan format .pdb.

\subsection{Prosedur Rinci ${ }^{14}$}

Penyiapan struktur protein dan struktur ligan. Pengunduhan makromolekul $\alpha$-glukosidase dari Protein Data Bank dengan format .pdb (PDB ID : 3a4a). Pengunduhan molekul ligan dari PubChem dengan format .pdb.

Penentuan Grid box. Tahapan penambatan molekuler dilakukan antara situs aktif $\alpha$-glukosidase yaitu daerah yang berinteraksi dengan ligan. Sebelum melakukan penambatan molekul, perlu disiapkan ukuran Grid Box dalam Autodock Tools 1.5.6. Penentuan grid box dilakukan untuk mengetahui titik koordinat pada active site dari a-glukosidase dengan menggunakan software Autodock Tools.

Preparasi file penambatan molekul. Merubah format file ligan menjadi .pdbqt dan reseptor yang dioptimasi dengan penambahan atom hidrogen menjadi .pdbqt dengan menggunakan software Autodock Tools. Data disimpan di drive $\mathrm{C}$ : dari windows.

Penambatan molekul dengan Autodock Vina. Ligan dan protein yang telah tersimpan dalam format .pdbqt dicopy ke dalam folder vina, kemudian config file vina diketik pada notepad, disimpan dengan nama .conf. File config berisi data terkait dengan nama reseptor, ligan, ukuran box, dan center box. Proses penambatan molekul dengan vina dijalankan melalui command prompt dengan parameter yang sesuai.

Penambatan molekuler. Penambatan molekul (docking) menggunakan aplikasi Vina dan memerlukan file enzim, ligan dan config. Penambatan molekul mulai dijalankan di Command prompt dalam folder yang terdapat file enzim, ligan dan file config. Proses penambatan molekul dijalankan dalam program vina. Setelah docking selesai akan diperoleh hasil beberapa mode docking beserta nilai Affinity (kkal/mol).

Analisis hasil penambatan molekuler. Analisis hasil docking meliputi nilai affinity dari beberapa mode hasil docking yang dapat dilihat dalam file Log.txt yang diperoleh. Analisis kedua yaitu melihat posisi ligan dari beberapa mode tersebut menggunakan software pymol. File enzim, ligan dan output docking dibuka dalam software pymol. Mode yang paling mirip dengan posisi ligan asli merupakan mode dengan pose terbaik.

Visualisasi. Visualisasi interaksi antara enzim dengan ligan dapat dilihat pada software Ligplot. Visualisasi yang dilakukan dengan melihat residu-residu asam amino yang dihasilkan. 


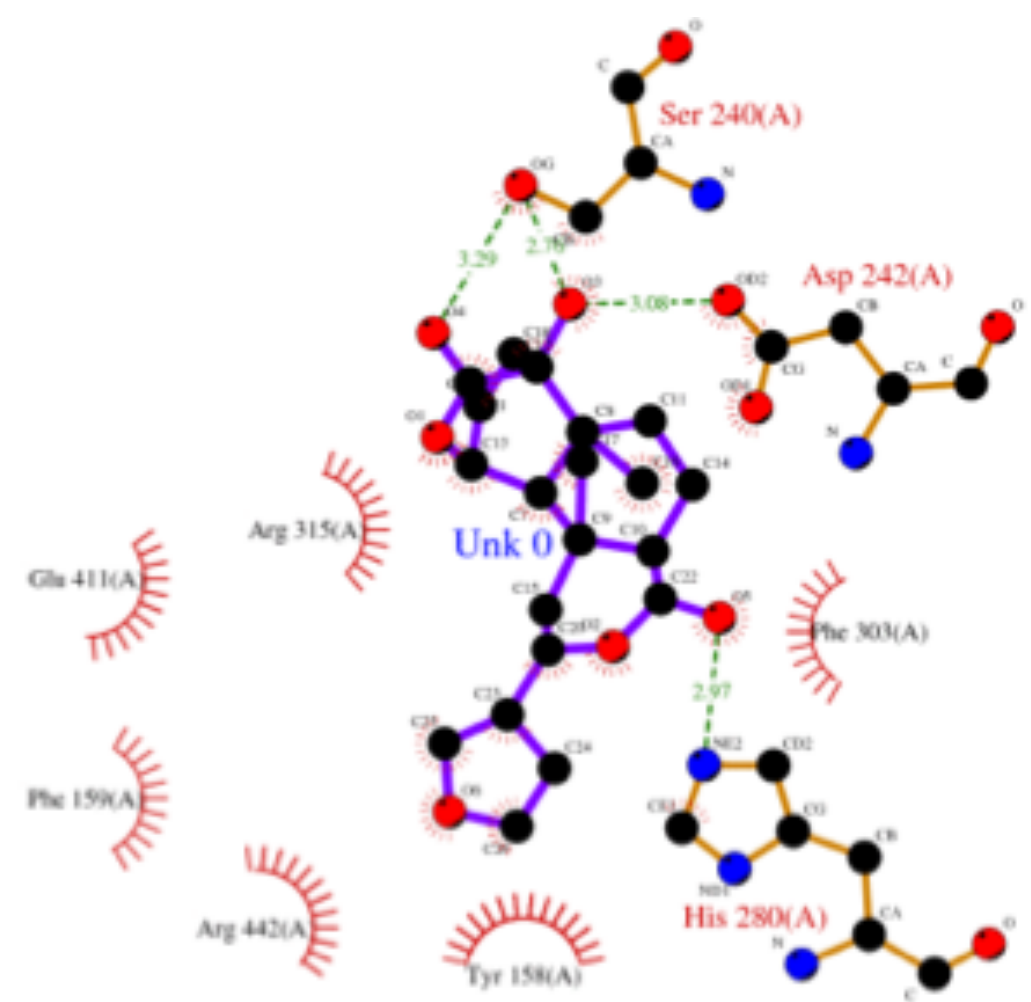

Gambar 1. Ikatan hidrogen dan hidrofobik yang terbentuk antara Columbin dengan Enzim $\alpha$-Glukosidase

3. Hasil

3.1. Penambatan Molekuler Ligan dengan Enzim $\alpha$-Glukosidase

Analisis data kromatogram yang dilakukan pada penelitian sebelumnya yang dilakukan oleh Wedaswari dengan menggunakan LC-MS, terdapat delapan senyawa yang teridentifikasi, dua senyawa yang memiliki kelimpahan paling banyak adalah schisandrin $\mathrm{B}$ dan Columbin yang diduga berpotensi sebagai inhibitor glukosidase (Tabel 1). Delapan senyawa tersebut kemudian dianalisis dengan metode komputasi (Penambatan Molekuler). Simulasi penambatan molekuler (docking) pada penelitian ini dilakukan dalam kondisi ligan fleksibel. Kondisi fleksibel digunakan untuk penyesuaian struktur ligan yang paling stabil berinteraksi dengan reseptor. Parameter kestabilan yang diamati adalah energi bebas Gibbs $(\Delta G)$. Semakin negatif nilai $\Delta G$ menunjukan tingkat kestabilan yang baik antara ligan dan reseptor, sehingga ikatan yang terbentuk akan semakin kuat. Tabel 1 menunjukan energi bebas Gibbs $(\Delta \mathrm{G})$ hasil simulasi docking, diperoleh hasil bahwa senyawa Columbin dan memiliki afinitas yang tinggi terhadap enzim ditunjukkan dengan nilai $\Delta \mathrm{G}$ yang rendah yaitu $-9 \mathrm{kcal}$. mol.<smiles>CCC(=O)c1cc(O)c(-c2cc(C(=O)CC)cc(OC)c2O)c(O)c1</smiles>

(a)<smiles>CC1(C)CC(=O)C(C(c2cccc(O)c2O)C2C(=O)C3=C(C(=O)CC(C)(C)C3)C2=O)=C(O)C1</smiles>

(b)

Gambar 2. (a) Columbin, (b) Schisandrin B 
Tabel 1. Parameter ligan untuk memenuhi aturan Lipinski dan ikatan afinitasnya (kkal/mol) dengan Saccharomyces cerevisiae $\alpha$-glukosidase

\begin{tabular}{|c|c|c|c|c|c|c|}
\hline Senyawa Dugaan & $\begin{array}{c}\text { Bobot } \\
\text { Molekul (m/z) }\end{array}$ & $\log \mathrm{P}$ & $\begin{array}{c}\text { Jumlah } \\
\text { Donor } \\
\text { Ikatan H }\end{array}$ & $\begin{array}{l}\text { Jumlah } \\
\text { Akseptor } \\
\text { Ikaatn H }\end{array}$ & $\begin{array}{l}\text { Binding affinity } \\
\text { (kcal.mol) }\end{array}$ & RMSD \\
\hline $\begin{array}{l}\text { Ethyl L-serinate } \\
\text { hydrochloride }\end{array}$ & 170,06 & 2,85 & 3 & 6 & $-4,4$ & 1,71 \\
\hline Schisandrin B & 401,19 & 0,37 & 3 & 4 & $-3,0$ & 1,23 \\
\hline Columbin & 359,15 & 2,48 & 2 & 6 & $-9,0$ & 1,42 \\
\hline $\begin{array}{l}\text { 4-(4-methoxy- } \\
\text { phenylamino)-2,3- } \\
\text { dihydro-1H-4a,9- } \\
\text { diaza-cyclopenta(b) } \\
\text { fluorine-10-carbonitrile }\end{array}$ & 355,16 & 4,35 & 5 & 1 & $-7,8$ & 1,37 \\
\hline $\begin{array}{l}\text { 6-Amino-4-[3-(benzyloxy) } \\
\text { phenyl]-3-tert-butyl-2,4- } \\
\text { dihydropyrano[2,3-c] } \\
\text { pyrazole-5-carbonitrile }\end{array}$ & 401,19 & 4,71 & 2 & 4 & $-7,5$ & 2,18 \\
\hline $\begin{array}{l}\text { 4-(\{4,6-Bis[(3R,5S)-3,5- } \\
\text { diamino-1-piperydinyl]- } \\
\text { 1,3,5-triazin-2-yl }\} \text { amino }) \\
\text { benzenesulfonamide }\end{array}$ & 478,25 & $-4,33$ & 11 & 13 & $-7,9$ & 1,71 \\
\hline $\begin{array}{l}\text { 1,1'-(1,4-butanediyl) } \\
\text { bis }\{2,6 \text {-dimethyl-4-[(3- } \\
\text { methyl-1,3-benzothiazol- } \\
\text { 2(3H)-ylidene)methyl] } \\
\text { pyridinium }\end{array}$ & 593,28 & $-1,14$ & 0 & 4 & $-4,7$ & 0,24 \\
\hline
\end{tabular}

3.2. Visualisasi Penambatan Ligan dengan Enzim $\alpha$-Glukosidase dengan LigPlot

Untuk mengetahui interaksi ligan dengan reseptor, maka dilakukan visualisasi dengan menggunakan LigPlot. Visualisasi hanya dilakukan terhadap senyawa Columbin yang merupakan senyawa yang memiliki interaksi yang kuat dengan enzim glukosidase. Hasil uji senyawa Columbin terhadap enzim $\alpha$-glukosidase (Gambar 1) menunjukkan bahwa, residu asam amino yang berinteraksi adalah Ser240, Asp242, His280, Arg315, Glu411, Phe159, Arg442, Tyr158 dan Phe303. Ikatan hidrogen terjadi dengan asam amino Ser40 dengan jarak ikatan $3.29 \AA$ dan 2.70 $\AA$, Asp242 dengan jarak ikatan $3.08 \AA$ dan His280 dengan jarak ikatan $2.97 \AA$. Analisis interaksi hidrofobik mengungkapkan senyawa Columbin memiliki interaksi hidrofobik dengan asam amino Arg315, Glu411, Phe159, Arg442, Tyr158 dan Phe303 (Gambar 1).

\section{Pembahasan}

4.1. Analisis Penambatan Molekuler Ligan dengan Enzim $\alpha$-Glukosidase

Sebelum dilakukan simulasi docking perlu dilakukan pengecekan sifat-sifat dari ligan yang digunakan, apakah memenuhi aturan Lipinski. Adapun aturan lipinski tersebut adalah suatu molekul dapat dilanjutkan simulasi docking apabila (1) berat molekul kurang dari 500 Da (2) nilai logP kurang dari 5, (3) jumlah donor ikatan hidrogen kurang dari 5 dan (4) jumlah akseptor ikatan hidrogen kurang dari $10 .{ }^{15}$ Aturan Lipinski dapat menentukan sifat fisikokimia ligan untuk menentukan karakter hidrofobik/ hidrofilik suatu senyawa untuk dapat melalui membran sel oleh difusi pasif. Nilai log $\mathrm{P}$ menyatakan koefisien kelarutan dalam lemak/ air yang memiliki rentang $-0,4-5$. Berat molekul yang lebih dari 500 Da tidak dapat berdifusi menembus membran sel. Semakin besar nilai $\log$ P, maka semakin hidrofobik molekul tersebut. Molekul yang memiliki sifat terlalu hidrofobik cenderung memiliki tingkat toksisitas yang tinggi karena akan tertahan lebih lama pada lipid bilayer dan terdistribusi 
lebih luas di dalam tubuh sehingga selektifitas ikatan terhadap enzim target menjadi berkurang. Nilai log $\mathrm{P}$ yang terlalu negatif juga tidak baik karena jika molekul tersebut tidak dapat melewati membran lipid bilayer. Jumlah donor dan akseptor ikatan hidrogen mendeskripsikan semakin tinggi kapasitas ikatan hidrogen, maka semakin tinggi energi yang dibutuhkan agar proses absorpsi dapat terjadi. Secara umum aturan Lipinski menggambarkan solubilitas senyawa tertentu untuk menembus membran sel oleh difusi pasif (Kunnumakkara 2008). Berdasarkan Tabel 1, ligan yang tidak sesuai dengan aturan lipinski adalah 4-( \{4,6- Bis [ $(3 \mathrm{R}, 5 \mathrm{~S})$ -3,5-diamino-1-piperydinyl ]-1,3,5-triazin2-yl\} amino) benzene sulfonamide dan $1,1^{\prime}-(1,4-$ butanediyl) bis $\{2,6$-dimethyl-4[(3-methyl-1,3-benzothiazol-2(3H)-ylidene) methyl ] pyridinium.

Validasi dilakukan untuk mendapatkan metode yang dapat dipercaya dan handal. Parameter yang digunakan yaitu RMSD (Root Mean Square Deviation), Bentuk ligan yang dipakai ditentukan berdasarkan besaran RMSD hasil perhitungan. Bentuk ligan dengan RMSD terkecil digunakan sebagai representasi bentuk interaksi antara ligan uji dengan protein. Hasil validasi metode didapatkan nilai RMSD $\leq 2 \AA$ (Tabel 1). Hasil tersebut menunjukkan hasil perhitungan docking antara protein dan ligan memberikan hasil yang hampir serupa karena memiliki nilai $\leq 2 \AA .{ }^{16}$ Simulasi docking dilakukan dengan menggunakan Autodock Vina. Reseptor yang digunakan dalam melakukan docking adalah struktur kristal dari $S$. cerevisiae (Kode PDB 3A4A) dengan melakukan penambatan molekuler di sekitar sisi aktif dari enzim, yaitu : Asp69, His112, Arg213, Asp215, Glu277, His351, Arg442 and Asp352. ${ }^{17}$ Letak gridbox berada dikoordinat $\mathrm{X}=24, \quad \mathrm{Y}=28 \quad \mathrm{Z}=36$ dan dimensi sebesar $X=21.272 \quad Y=-0.763$ $\mathrm{Z}=18.640$. Gridbox merupakan daerah yang membatasi ligan untuk berinteraksi dengan enzim, sehingga ligan melakukan docking secara terarah didaerah sekitar sisi aktif dari enzim. Sruktur ligan yang digunakan diambil dari PubChem yang disimpan dalam bentuk .sdf kemudian diubah dalam bentuk .pdb menggunakan discovery studio. Hasil simulasi docking yang dilakukan sebanyak 8 kali memiliki 8 pose hasil docking yang memiliki energi ikatan masing-masing. Adapun energi ikatan yang diambil adalah yang paling negatif karena memiliki interaksi yang kuat. Binding affinity merupakan ukuran kemampuan obat untuk berikatan dengan reseptor. Semakin kecil nilai binding affinity maka afinitas antara reseptor dengan ligan semakin tinggi begitu pula sebaliknya jika semakin besar nilai binding maka afinitas antara reseptor semakin rendah. Hasil data seperti yang diperlihatkan pada Tabel 1 . Dari Tabel 1 dapat diketahui hasil dari uji in silico aktivitas senyawa daun sirih merah dengan enzim glukosidase memprediksikan bahwa ligan yang lebih stabil terhadap enzim glukosidase adalah senyawa Columbin dengan nilai energi ikatan yaitu $-9.0 \mathrm{kcal}$. mol. Hal ini dikarenakan adanya gugus-gugus fungsi polar pada ligan seperti metil $\left(-\mathrm{CH}_{3}\right)$, hidroksil $(-\mathrm{OH})$ dan amina $\left(-\mathrm{NH}_{3}\right)$ pada ligan.

Senyawa-senyawa bioaktif yang terkandung didalam fraksi etil asetat, beberapa diantaranya telah diketahui memiliki aktivitas sebagai antidiabetes, yaitu Schisandrin B (SchB) dan Columbin. Schisandrin B (SchB) adalah salah satu turunan dibenzocyclooctadiene yang paling banyak dan aktif yang ditemukan di buah Schisandra chinensis. SchB dilaporkan dapat meningkatkan aktivitas superoksida dismutase (SOD), meningkatkan kemampuan antioksidan dan radikal bebas oksigen, mengurangi tingkat peroksidasi lipid dan juga ekspresi GLUT4 mRNA ditingkatkan dalam jaringan otot, sehingga meningkatkan transportasi kapasitas glukosa, mengurangi glukosa darah, memperbaiki fungsi hati sebagai antiinflamasi dan antioksidan. ${ }^{18}$ Kemampuan schisandrin B sebagai antioksidan ini berperan dalam melindungi sel beta pankreas sehingga dapat meningkatkan sekresi insulin. Senyawa columbin mengatur sintesis kolesterol dan glikolisis. Meningkatkan aktivitas glukokinase hati, yaitu enzim yang mengkatalisis glukosa menajdi glukosa 6 fofat. Columbin juga berperan menurunkan aktivitas glukosa 6 
fosfat dan fosfoenolpiruvat karboksikinase, hal ini menyebabkan peningkatan glikogen di hati dan menurunkan kadar glukosa dalam darah. ${ }^{19}$

Dari kedua struktur senyawa yang diduga berperan dalam menghambat enzim $\alpha$-glukosidase, dapat diketahui bahwa gugus hidroksi yang terdapat pada columbin (gambar 2a) dan schisandrin B (gambar 2b) dapat meningkatkan kemampuan inhibisi enzim $\alpha$-glukosidase, gugus $\mathrm{OH}, \mathrm{CH} 3$ dan NH3 berperan dalam interaksi dengan sisi aktif dari enzim $\alpha$-glukosidase melalui ikatan hidrogen ${ }^{20}$ (Gambar 2).

\subsection{Interaksi Ikatan Hidrogen dan Hidrofobik Ligan dengan Enzim $\alpha$-Glukosidase}

Fraksi aktif yang dipilih adalah fraksi etil asetat. Semua senyawa yang diisolasi (Tabel 1) dievaluasi dengan metode docking untuk mengetahui interaksi antara Ligan dengan enzim glukosidase. Senyawa Columbin menunjukkan paling kuat aktivitas penghambatan terhadap enzim $\alpha$-glukosidase. Visualisasi selanjutnya dilakukan untuk mengetahui interaksi senyawa Columbin di dalam kantong sisi aktif enzim target. Visualisasi interaksi senyawa-senyawa uji di dalam kantong sisi aktif enzim target dengan LigPlot ${ }^{21}$ menunjukkan interaksi ikatan (non kovalen) dengan residu asam amino pada kantong sisi aktif yang secara hipotesis mempengaruhi aktivitas biologis penghambatan ${ }^{22}$ dan juga interaksi hidrofobik yang menilai kestabilan interaksi konformasi struktur 3D senyawa uji dalam lingkungan konformasi terbuka kantong sisi aktif enzim target. ${ }^{23}$ Columbin mengandung gugus $\mathrm{OH}$ dan $\mathrm{CH}_{3}$. Kedua gugus ini bisa terbentuk ikatan hidrogen dengan residu asam amino kompleks reseptor. Interaksi ikatan hidrogen dan panjang ikatan Columbin divisualisasikan dan dihitung oleh Ligplot (Gambar 1). Interaksi yang mengikat dapat mengakibatkan penghambatan enzim. Energi pengikatan Columbin dengan residu yang berinteraksi baik berupa ikatan hidrogen maupun hidrofobik beserta panjang ikatannya dengan struktur kristal dari $\alpha$-glukosidase yang disajikan pada Gambar 1, yaitu Ser240, Asp242, His280, Arg315, Glu411, Phe159, Arg442, Tyr158 dan Phe303. Terdapat empat ikatan $\mathrm{H}$ antara Columbin dan enzim glukosidase, yaitu His280 dengan jarak 2.97 Å, Asp242 dengan jarak $3.08 \AA$, Ser240 dengan jarak $3.29 \AA$ dan $2.70 \AA$. Analisis interaksi hidrofobik mengungkapkan senyawa Columbin memiliki interaksi hidrofobik dengan asam amino Arg315, Glu411, he159, Arg442, Tyr158 dan Phe303 (Gambar 1).

Senyawa Columbin berinteraksi dengan residu katalitik His280, Asp242 dan Ser240. Senyawa Columbin membentuk empat ikatan hidrogen dengan Asp242, Ser240 dan His280, ikatan tersebut menstabilkan komplek ligan dengan protein. Senyawa Columbin mengikat dibantu secara dominan melalui kontak hidrofobik yang berkontribusi terhadap energi ikatnya sehingga mencerminkan aktivitas penghambatannya. Fenomena ini dapat menyebabkan substrat tidak terikat di situs aktif enzim, yang dapat memperlambat aktivitas protein. ${ }^{24}$ Adanya interaksihidrofobik dengan asam amino Arg315, Glu411, Phe159, Arg442, Tyr158 dan Phe303 menyebabkan penutupan kantong untuk mencegah pintu masuk substrat, yang selanjutnya bertindak sebagai sifat penghambat kompetitif. Hal ini diperkuat dengan penelitian yang dilakukan oleh Shivanagoudra terhadap ekstrak etil asetat buah melon cina dimana senyawa 25 -isopropenylchole-5,(6)-ene-3-O- $\beta$ Dglucopyranoside (IDG) yang terkandung didalam ekstrak etil aseat buah melon cina terikat pada residu Leu313, Asp242, Pro312, Val308, Val319 dan His280 di katalitik situs glukosidase. ${ }^{25}$ IDG menghasilkan pose docking terbaik dibandingkan senyawa lain, yaitu 25-trihydroxycucurbita-5, 23(E)-dien19-al (TCD) and charantaB yang diisolasi dari ekstrak etil asetat daun M. Charantina dengan energi ikat minimum -10,58 kkal / mol. Ligan dikelilingi oleh residu katalitik Asp 242 dan interaksi itu mungkin penting untuk penghambatan glukosidase. Tiga ikatan hidrogen terbentuk dengan asam amino Leu313 (3,94 dan 4,98 Å) dan Asp242 (5,16 $\AA$ ). Ikatan hidrogen ini memperkuat interaksi antara IDG dan glukosidase. Penelitian lain 
yang serupa masing-masing. Hal ini diperkuat dengan penelitian yang dilakukan oleh Sari et al. terhadap akarbose, dimana situs aktif di sekitar akarbose divisualisasikan dan dihitung dengan PyMOL dan Ligplot. Akarbose dikelilingi oleh 18 residu asam amino sebagai situs aktifnya: Asp69, Tyr72, Tyr158, Phe159, Phe178, Asp215, Val216, Glu277, Glu279, Phe303, Asp307, Thr310, Ser311, Arg315, Asp352, Glu411 dan Arg442. ${ }^{25}$ Interaksi yang mengikat dapat mengakibatkan penghambatan enzim. Peningkatan energi ikat meningkatkan simultan dalam energi ikat sehingga menyebabkan akarbose menghambat enzim $\alpha$-Glukosidase secara kompetiti. ${ }^{26}$

\section{Simpulan}

Berdasarkan hasil penelitian dapat diambil kesimpulan bahwa interaksi senyawa Columbin terhadap enzim $\alpha$-glukosidase dengan nilai energi bebas terendah yaitu, $-9,0 \mathrm{kcal} / \mathrm{mol}$. Situs pengikatan senyawa Columbin dengan asam amino Ser240, Asp242, His280, Arg315, Glu411, Phe159, Arg442, Tyr158 dan Phe303.

\section{Daftar Pustaka}

1. [ADA] American Diabetes Association. 2012. Diagnosis and classification of diabetes mellitus. Diabetes Care. 2012;35:S64-71

2. Tripathi, B. K. \& Srivastava, A. K. Diabetes mellitus: Complications and therapeutics, Med Sci Monit. 2006; 12 (7):131-138.

3. Rais, I.R., A.G. Samudra, S. Widyarini dan A.E. Nugroho. Penentuan Aktivitas Isolat Andrografolid Terhadap a-Amilase dan a-Glukosidase Menggunakan Metode Apostolid dan Mayur. Jurnal Tradisional Medis. 2013; 18(3):162-166.

4. Inzucchi SE, Bergenstal RM, Buse JB, Diamant M, Ferrannini E, Nauck M, Matthews DR. Management of hyperglycemia in type 2 diabetes : a patient-centered approach: update to a position statement of the American Diabetes Association and the

European Association for the study of diabetes. Diabetes Care. 2015;38(1): 140-
149.

5. Malviya N, Jain S, Malviya S. Antidiabetic potential of medicinal plants. Acta Poloniae Pharmaceutica-Drug Research. 2010; 67(2): 113-118.

6. Joelijanto R. The Potential of Red Betel (Piper crocatum Ruiz) as a Space Maintainer Natural Cleanser in Orthodontic Treatment. The Indonesian Journal of Dental Research. 2012.

7. PujiastutiP,LestariS.Perbedaanefektivitas antibakteri ekstrak daun sirih merah (Piper crocatum) pada Porphyromonas gingivalis dan Sterptococcus viridans. Jurnal Stomatognati. 2015;1(1):1-6.

8. Safithri M, Yasni S, Yasni S, Bintang M, Ranti AS. Antihyperglycemic Activity of Piper crocatm Leaves and Cinnamomum burmannii Bark Mixture Extract in Streptozotocin-induced Diabetic Rats. Journal of Mathematical and Fundametal Sciences. 2016;48(2):178-191

9. Puspa SD, Ita NA. Pengaruh Pemberian Ekstrak Etanol Sirih Merah terhadap Kadar Glukosa Darah pada Tikus Wistar Jantan Model Hiperkolesterolemia. Kartika Jurnal Ilmiah Farmasi 2014;2 (2):7-13 7 ISSN 2354-6565

10. Alfarabi M. Bintang M. Suryani. Safitri M. The Comparative Ability of Antioxidant Activity of Piper crocatum in Inhibiting Fatty Acid Oxidation and Free Radical Scavenging. Hayati Journal of Biosciences. 2010; 17(4) :201-204

11. Yamamoto, K., Miyake, H., Kusunoki, M., and Osaki, S. Crystal structures of isomaltase from Saccharomyces cerevisiae and in complex with its competitive inhibitor maltose, FEBS J. 2010;277 (20):4205-4214

12. Weni $M$ et al. Studi In Vitro dan Penambatan Molekuler Senyawa Bioaktif Ekstrak dan Fraksi Daun Sirih Merah (Piper crocatum) sebagai Inhibitor $\alpha$-Glukosidase [laporan penelitian]. Bogor(ID): IPB. 2018.

13. Wedaswari IAI. Aktivitas Antioksidan Ekstrak Etanol dan Fraksi Daun Sirih Merah (Piper crocatum) dengan Metode Rancimat dan Identifikasi dengan LC- 
MS. [skripsi]. Bogor: Institut Pertanian Bogor.2018.

14. Setiawan T. Studi molecular docking ekstrak kurkuminoid asal wonogiri sebagai inhibitor enzim dna topoisomerase II [skripsi]. Bogor(ID): IPB. 2015.

15. Kunnumakkara A.B, Anand P, Aggarwal, BB. Curcumin Inhibots Proliferation, Invasion, Angiogenesis and Metastasis of Different Cancers Through Interaction with Multiple Cell Signaling Proteins. 2008.

16. Mihasan M. What in silico molecular docking can do for the bench-working biologists. J. Biosci. 2012;37(6) .

17. Kwan HY, Wu J, Su T, Chao XJ, Yu H, Liu B, Fu X, Tse AKW, Chan CL, Fong WF, Yu Z. 2017. Schisandrin B regulates lipid metabolism in subcutaneous adipocytes. Scientific Reports. 7: 10266. DOI: $10.1038 / \mathrm{s} 41598-017-10385-\mathrm{z}$

18. Bharti SK, Krishnan S, Kuwar A, Kumar A. Antidiabetic phytoconstituents and their mode of action on metabolic pathways. Ther Adv Endocrinol Metab. 2018;9(3):81-100

19. Xu H. Inhibition Kinetics of Flavonoids on Yeast a-Glucosidase Merged with Docking Simulation. 2010;17(10): 12701279.

20. Thomas G. Fundamentals of Medicinal Chemistry. John Wiley \& Sons Ltd. UK.
2013.

21. Preziosi, L. Cancer Modelling and Simulation. Chapman \& Hall/CRC. Florida. 2003.

22. Hubbard, R.E., dan Haider, M.K. 2010. Hydrogen Bond in Protein: Role and Strength". [diakses 2 Maret 2019]. Wiley Online Library

23. Lavle, N.; Shukla, P.; Panchal, A. ROLE of flavonoids and saponins in the treatment of diabetes mellitus. J. Pharm. Sci. Bioscientific Res 2016;6:535-541.

24. Shivanagoudra R, Perera WH, Perez JL. Cucurbitane-type compounds from Momordica charania : Isolation, in Vitro Antidiabetic, Anti-Inflammatory Activities and in Silico Modeling Approaches. J.Bioorganic Chemistry. 2019;87:31-42

25. Sari BL, Mun'im A, Yanuar A, Riadhi R. Screening of $\alpha$-Glukosidase Inhibitors From Terminalia Catappa L. Fruits Using Molecular Docking Method and In Vitro Test. Int J Pharm Sci 2016;8(12) : 184189

26. Prenca C, Freitas M, Ribeiro D et al. $\alpha$-Glucosidase inhibition by flavonoids: an in vitro and in silico structureactivity relationship study. J. of Enzym Inhibition and Medical Chemistry. . 2017;32(1):1216-1228 